\title{
Finansiële beoordeling van landboukoöperasies
}

\author{
W.D. Hamman \\ Nagraadse Bestuurskool, Universiteit van Stellenbosch, Posbus 610, Bellville, 7535 Republiek van Suid-Afrika

\section{I.J. Lambrechts* en F.J. Mostert} \\ Departement Bedryfsekonomie, Universiteit van Stellenbosch, Stellenbosch, 7600 Republiek van Suid-Afrikar
}

Ontvang 30 Junie 1987; aanvaar 16 September 1987

\begin{abstract}
This article covers a financial evaluation of 31 representative agricultural co-operatives. Although the ratio of the members' interest to the total assets remained reasonably constant during the study period, the share capital and reserves decreased relatively to the total assets. According to the financial evaluation, it is clear that there is a high gearing ratio, because about $75 \%$ of the total capital structure consists of loan capital. Although the asset structure showed no substantial change, the composition of current assets (which represented about $75 \%$ of the total assets) changed significantly. The debtors increased considerably whilst a decrease in the inventory cancelled this increase. Therefore it is apparent that the co-operatives fulfill the functions of financial institutions to a large extent. Looking at the liquidity position, the current assets increased relatively to the current liabilities, while a defensive financing policy was applied because the fixed assets, investments and intangible assets were financed by long-term capital. An analysis of the turnover ratios showed that the amounts of the total assets, debtors and current assets increased more rapidly than the sales volume, which may be the result of a more liberal credit policy towards members, the drought in certain parts of the country as well as an over-capitalization of the co-operatives. Although the average profitability was rather low, it must be seen against the background of a service rendered instead of a striving towards a profit. According to available information, it appears that the ability to meet their interest obligations deteriorated seriously since 1982.
\end{abstract}

Hierdie artikel behels ' $n$ finansiële beoordeling van 31 verteenwoordigende landboukoöperasies. Alhoewel die ledebelang in verhouding tot die totale bates gedurende die studieperiode redelik konstant gebly het, het die aandelekapitaal en reserwes relatief tot die totale bates afgeneem. Uit die finansiële beoordeling van die ondernemings blyk dit verder dat daar 'n hoë hefboomverhouding is aangesien leningskapitaal ongeveer $75 \%$ van die totale kapitaal uitmaak. Alhoewel die batestruktuur geen wesenlike verandering toon nie, het die samestelling van die vlottende bates (wat bykans $75 \%$ van die totale bates uitmaak), noemenswaardig verander. So het die debiteure aansienlik toegeneem terwyl 'n daling in voorraad weer die betrokke tocname uitgekanselleer het. Dit wil gevolglik voorkom asof koöperasies in 'n groot mate dic funksie van finansiële instellings begin verrig het. Met verwysing na die likiditeitsposisie, het die vlottende bates in verhouding met die vlottende laste toegeneem, terwyl 'n defensiewe finansieringsbeleid aanwesig was aangesien die vaste bates, beleggings en ontasbare bates deur langtermynkapitaal gefinansier is. 'n Ontleding van die betrokke omloopsnelhede het voorts getoon dat die omvang van die totale bates, debiteure en vlottende bates vinniger as die verkoopsomvang toegeneem het, wat die gevolg kan wees van 'n moontlike verslapping in die kredietbeleid teenoor die lede, die droogtetoestande in sekere dele van die land asook dic oorkapitalisasie van koöperasies. Wat die winsgewendheid betref, is die ondernemingsrentabiliteit relatief laag, maar moet die beoordeling egter teen die agtergrond van dienslewering (eerder as 'n winsmotief) gesien word. Beskikbare inligting toon verder dat die vermoë om renteverpligtinge na te kom vanaf 1982 ernstig verswak het.

\section{- Aan wie korrespondensie gerig moet word}

Kapitaalvorming is gedurende 1975 tot 1985 by 31 koöperasies ondersoek in opdrag van die SuidAfrikaanse Landbou-unie en terselfdertyd is 'n ontleding van hulle finansiële situasie gedoen. Hierdie koöperasies het werk aan bykans 50000 mense verskaf waarvan $60 \%$ swart werknemers was. Die betrokke ondernemings se totale bates het meer as $67 \%$ van die totale bates van alle Suid-Afrikaanse landboukoöperasies bedra en derhalwe is die 31 koöperasies as redelik verteenwoordigend van alle landboukoöperasies beskou in terme van totale bates.

Die finansiële ontleding van die koöperasies asook hulle meegaande kapitaalvorming moet teen die agtergrond van 'n aantal belangrike veranderinge in die betrokke bedryfsomgewing beskou word. So is koöperasies vanaf 1 April 1977 belastingpligtig, maar as 'n oorgangsmaatreël is hulle toegelaat om gedurende die eerste 10 jaar (wat op 1 April 1977 gevolg het) die terugbetaling van lenings wat (volgens die Kommissaris van Binnelandse Inkomste) aangegaan is om fasiliteite vir die opberging en/of primêre verwerking van die betrokke lede se produkte, af te trek wanneer die belasbare inkomste vasgestel word. Verder is uitgestelde bonusse verklaar deur koöperasies, aftrekbaar vir belastingdoeleindes, terwyl dit in die hande van die lede belasbaar is.

Koöperasies is voorts beïnvloed deur die hoë rentekoerse wat veral gedurende 1984 en 1985 ongehoorde hoë vlakke bereik het, terwyl die Landbank 
wat 'n belangrike finansieringsbron van koöperasies is, markverwante rentekoerse begin hef het. Saam met die belastingpligtigheid van koöperasies en die hoë rentekoerse, is die landbousektor in sekere dele van die land ook deur voortdurende droogte getref wat 'n addisionele las op die koöperasiewese geplaas het.

\section{Finansiële beoordeling van koöperasies}

Alhoewel die ledebelang (te wete aandelekapitaal, uitgestelde bonusse, reserwes, ledeheffingsfondse en ander fondse) in verhouding tot die totale bates gedurende die 11 jaar redelik konstant gebly het, het die aandelekapitaal en reserwes relatief tot die totale bates 'n afname getoon. Die koöperasies het 'n hoë hefboomverhouding omdat leningskapitaal by verre die grootste komponent (ongeveer $75 \%$ ) van die totale kapitaal uitmaak.

Die batestruktuur van die koöperasies het geen wesenlike verandering ondergaan gedurende die studieperiode nie, soos dit uit Tabel 1 blyk. Terwyl vaste bates ongcveer $20 \%$ van die totale bates uitmaak, bedra vlottende bates bykans $75 \%$ van die totale bates. Die grootste komponent van vlottende bates is debiteure wat in 1985 sowat die helfte van die totale bates uitgemaak het in teenstelling met ongeveer $20 \%$ in 1975 . Daar het dus ' $n$ aansienlike verskuiwing in die vlottende bates plaasgevind aangesien die styging in debiteure hoofsaaklik deur die daling in voorraad uitgekanselleer is. Dit wil gevolglik voorkom asof koöperasies in 'n groot mate die funksie van finansiële instellings begin verrig het.
Wat die likiditeitsbeoordeling betref, het die eerste likiditeitsverhouding gedurende die 11 jaar 'n stabiele verloop getoon (sien Tabel 2), wat aandui dat vlottende bates in verhouding tot vlottende laste toegeneem het. Die tweede likiditeitsverhouding het gedurende die studieperiode 'n stygende tendens getoon (volgens Tabel 2) wat beteken dat vlottende bates, met die uitsluiting van voorrade, vinniger as vlottende laste gestyg het. Die feit dat die tweede likiditeitsverhouding toegeneem het, is nie noodwendig ' $n$ aanduiding dat die betrokke koöperasies se likiditeit verbeter het nie, omdat dit hoofsaaklik deur die toename in debiteure bewerkstellig is. Die likiditeit van die betrokke debiteure sal derhalwe in ag geneem moet word voordat 'n likiditeitsverbetering van die koöperasies ter sprake kan kom.

Wat die finansieringswyse van die bates betref, het dit uit die finansiële beoordeling geblyk dat die vaste bates, beleggings en ontasbare bates deur die langtermynkapitaal (naamlik ledebelang en langtermynlenings) gefinansier word (sien Tabel 2). 'n Defensiewe finansieringbeleid word derhalwe deur die koöperasies gevolg omdat bates wat langtermyn van aard is met langtermyn en/of permanente kapitaal gefinansier word en gevolglik word likiditeitsprobleme vermy.

Die omloopsnelhede van totale bates, debiteure en vlottende bates het 'n dalende tendens getoon soos blyk uit Tabel 3. Die afleiding kan gevolglik gemaak word dat die omsette van die koöperasies nie met die balansstaatitems se veranderinge tred gehou het nie. Redes vir hierdie bevinding behels moontlik 'n verslapping in die kredietbeleid teenoor die lede, die droogtetoestand in

Tabel 1 Verhoudingsgetalle van die koöperasies se batestruktuur

\begin{tabular}{|c|c|c|c|c|c|c|c|c|c|c|c|}
\hline & 1975 & 1976 & 1977 & 1978 & 1979 & 1980 & 1981 & 1982 & 1983 & 1984 & 1985 \\
\hline Vaste bates/totale bates $\times 100$ & 19,42 & 21,46 & 22.10 & 21,76 & 21,22 & 19,82 & 18,49 & 16,86 & 19,25 & 21,05 & 18.61 \\
\hline \multicolumn{12}{|l|}{ (Vaste bates + beleggings + ontasbare bates $) /$} \\
\hline totale bates $\times 100$ & 24,69 & 27,60 & 27,84 & 26,88 & 26,10 & 24,65 & 23,85 & 22,15 & 24,97 & 26,87 & 22,09 \\
\hline Vlottende bates/totale bates $\times 100$ & 75,28 & 72,13 & 71.55 & 72,85 & 73,65 & 75,19 & 75,93 & 77,52 & 74,83 & 73.01 & 77,74 \\
\hline Ander bates/totale bates $\times 100$ & 0,03 & 0,27 & 0,61 & 0,28 & 0,25 & 0,16 & 0,32 & 0,32 & 0,20 & 0,12 & 0,17 \\
\hline
\end{tabular}

Tabel 2 Verskillende finansiële verhoudings van die koöperasies

\begin{tabular}{lccccc}
\hline & $\begin{array}{c}\text { Eerste likidi- } \\
\text { teitsverhouding }\end{array}$ & $\begin{array}{c}\text { Tweede likidi- } \\
\text { teitsverhouding }\end{array}$ & $\begin{array}{c}\text { (Ledebelang + langtermynlenings)/ } \\
\text { (Vaste bates + beleggings + ontasbare } \\
\text { bates) } \times 100\end{array}$ & $\begin{array}{c}\text { Ondernemings- } \\
\text { rentabiliteit }\end{array}$ & $\begin{array}{c}\text { Surplus voor rente en belasting/ } \\
\text { netto renteverpligtinge }\end{array}$ \\
\hline 1975 & 1,18 & 0,41 & 146,47 & 9,56 & 2,36 \\
1976 & 1,15 & 0,47 & 134,89 & 10,92 & 2,09 \\
1977 & 1,16 & 0,54 & 137,68 & 9,65 & 1,76 \\
1978 & 1,17 & 0,53 & 139,85 & 9,95 & 1,46 \\
1979 & 1,16 & 0,52 & 139,46 & 8,88 & 1,64 \\
1980 & 1,16 & 0,57 & 142,67 & 8,44 & 1,00 \\
1981 & 1,17 & 0,58 & 147,06 & 10,47 & 1,44 \\
1982 & 1,12 & 0,49 & 137,77 & 11,56 & 1,22 \\
1983 & 1,13 & 0,60 & 134,82 & 12,28 & 1,24 \\
1984 & 1,14 & 0,78 & 134,04 & 10,63 & 1,10 \\
1985 & 1,16 & 0,80 & 148,26 & 10,28 & \\
\hline
\end{tabular}


sekere dele van die land asook die oorkapitalisasie van koöperasies.

Die ondernemingsrentabiliteit van die 31 koöperasies (bereken volgens die verhouding surplus voor rente en belasting / gemiddelde totale kapitaal $\times 100$ ) het gedurende die studieperiode tussen $8,44 \%$ en $12,28 \%$ gefluktueer (Tabel 2). Alhoewel die relatief lae rentabiliteit van die koöperasies teen die agtergrond van dienslewering (eerder as 'n winsmotief) gesien moet word, moet die betrokke rentabiliteit tog seker voldoende wees om die verskaffers van eie kapitaal 'n aanvaarbare vergoeding te bied, die renteverpligtinge na te kom en om verder deur middel van die reservering van netto inkomste te voorsien vir die hoër vervangingswaarde van die bates.

Uit die beskikbare inligting blyk dit dat die vermoë van die koöperasies om hulle renteverpligtinge na te kom vanaf 1982 ernstig verswak het omdat die dekkingsverhouding van die renteverpligtinge (te wete die surplus voor rente en belasting / die netto renteverpligtinge) in 1985 slegs 1,1 beloop het in vergelyking met 2,36 in 1975 (na aanleiding van Tabel 2). Moontlike redes vir hierdie resultaat kan die toename in rentekoerse gedurende die afgelope paar jaar wees asook die nadelige uitwerking van die droogtetoestande.

Tabel 3 Die omloopsnelhede van verskillende bates van die koöperasies

$\begin{array}{llll}1981 & 1982 & 1983 & 1984\end{array}$

\begin{tabular}{lrrrr}
\hline Omloopsnelheid van & & & & \\
Totale bates & 1,75 & 1,64 & 1,41 & 1,25 \\
Voorrade & 4,58 & 3,97 & 3,59 & 4,30 \\
Debiteure & 5,04 & 4,97 & 4,12 & 3,05 \\
Vlottende bates & 2,32 & 2,14 & 1,85 & 1,69 \\
Netto vlottende bates & 16,46 & 17,79 & 16,97 & 14,27 \\
\hline
\end{tabular}

Weens die beperkte beskikbare inligting kon die omloopsnelhede slegs vir 1981 tot 1984 bereken word

\section{Samevatting}

Die finansiële beoordeling van die 31 koöperasies het ' $n$ aantal probleme geïdentifiseer. So blyk dit dat die hoë hefboomverhouding gelei het tot die ernstige verswakking in die vermoë van die koöperasies om sedert 1982 hulle renteverpligtinge na te kom. Die feit dat debiteure 'n al hoe groter komponent van die vlottende bates begin vorm het, kan moontlik gesien word as 'n oorname van finansiële instellings se funksie deur koöperasies. Verdere probleme kom na vore wanneer die betrokke omloopsnelhede toon dat die omvang van die totale bates, debiteure en vlottende bates gedurende die studieperiode vinniger as die verkoopsomvang van die koöperasies toegeneem het. Die verandering in die finansiële situasie van die koöperasies het 'n baie duidelike uitwerking op hulle kapitaalvorming gehad; 'n aspek wat in 'n volgende artikel bespreek word.

\section{Summary}

This article covers a financial evaluation of 31 representative agricultural cooperatives. The financial evaluation must be seen against the background of a number of significant changes in their business environment. Cooperatives have been taxable since 1977 , but they were to deduct the redemption of certain loans for 10 years in the calculation of taxable income as a temporary measure. Deferred bonusses are also deductible by cooperatives for income purposes whilst members do pay income tax on deferred bonusses. Cooperatives were also influenced by the high interest rates which reached excessive high levels in 1984 and 1985. The Land Bank which was an important source of financing for cooperatives started to charge marketrelated interest rates. Together with the taxability of the cooperatives and the high interest rates, the agricultural sector was also subject to a continuous drought which put an additional burden on cooperatives. The changes in the financial ability of cooperatives should therefore be seen against the light of these changes. Although the ratio of the members' interest to the total assets remained reasonably constant during the study period, the share capital and reserves decreased relatively to the total assets. According to the financial evaluation, it is clear that there is a high gearing ratio, because about $75 \%$ of the total capital structure consists of loan capital. Although the asset structure showed no substantial change, the composition of current assets (which represented about $75 \%$ of the total assets) changed significantly. The debtors increased considerably while a decrease in the inventory cancelled this increase. Therefore it is apparent that the cooperatives fulfill the functions of financial institutions to a large extent. Looking at the liquidity position, the current assets increased relatively to the current liabilities, while a defensive financing policy was applied because the fixed assets, investments and intangible assets were financed by long-term capital. An analysis of the turnover ratios showed that the amounts of the total assets, debtors and current assets increased more rapidly than the sales volume, which may be the result of a more liberal credit policy towards members, the drought in certain parts of the country as well as an over capitalization of the cooperatives. Although the average profitability was rather low, it must be seen against the background of a service rendered instead of a striving towards a profit. According to available information, it appears that the ability to meet their interest obligations deteriorated seriously since 1982 .

The financial evaluation of the 31 cooperatives identified a number of problems. It should be kept in mind that the total assets of these cooperatives represented $67 \%$ of the total assets of South African agricultural cooperatives and are therefore representative of all agricultural cooperatives in terms of total assets. The high gearing ratio resulted in a serious deterioration of the ability of cooperatives to cover their interest obligations since 1982 . The fact that debtors as a percentage of total current assets increased considerably 
is as a result of the financing function of the banks being taken over by the cooperatives to a certain degree. This places an additional burden on co-operatives in fulfilling their main function. Further problems result from decreasing turnover ratios which indicate that the increases in the turnovers were less than the increases in the assets. The changes in the financial ability of cooperatives had an important effect on their capital formation, an aspect which will be covered in a subsequent article. 